OPEN ACCESS

Edited by:

Justin John Yerbury,

University of Wollongong, Australia

Reviewed by:

Dean Louis Pountney,

Griffith University, Australia

Luísa V. Lopes,

Universidade de Lisboa, Portugal

*Correspondence: Jiukuan Hao

haojn@uc.edu

Specialty section: This article was submitted to

Neurodegeneration,

a section of the journal

Frontiers in Neuroscience

Received: 10 November 2016 Accepted: 28 April 2017

Published: 29 May 2017

Citation:

Hu J, Ferchmin PA, Hemmerle AM, Seroogy KB, Eterovic VA and Hao J

(2017) 4R-Cembranoid Improves Outcomes after 6-Hydroxydopamine Challenge in Both In vitro and In vivo Models of Parkinson's Disease. Front. Neurosci. 11:272 doi: 10.3389/fnins.2017.00272

\section{R-Cembranoid Improves Outcomes after 6-Hydroxydopamine Challenge in Both In vitro and In vivo Models of Parkinson's Disease}

\author{
Jing Hu ${ }^{1}$, P. A. Ferchmin ${ }^{2}$, Ann M. Hemmerle ${ }^{3}$, Kim B. Seroogy ${ }^{3}$, Vesna A. Eterovic ${ }^{2}$ and \\ Jiukuan Hao ${ }^{1 *}$ \\ ${ }^{1}$ Division of Pharmaceutical Sciences, James L. Winkle College of Pharmacy, University of Cincinnati, Cincinnati, OH, \\ United States, ${ }^{2}$ Department of Neurosciences, School of Medicine, Universidad Central del Caribe, Bayamón, Puerto Rico, \\ ${ }^{3}$ Department of Neurology and Rehabilitation Medicine, University of Cincinnati, Cincinnati, $\mathrm{OH}$, United States
}

(1S, 2E, 4R, 6R,-7E, 11E)-2, 7, 11-cembratriene-4, 6-diol (4R) is one of the cembranoids found in tobacco leaves. Previous studies have found that $4 \mathrm{R}$ protected acute rat hippocampal slices against neurotoxicity induced by $\mathrm{N}$-methyl-D-aspartate (NMDA) and against the toxic organophosphorus compounds paraoxon and diisopropylfluorophosphate (DFP). Furthermore, in vivo, 4R reduced the infarct size in a rodent ischemic stroke model and neurodegeneration caused by DFP. The present study expanded our previous study by focusing on the effect of 4R in Parkinson's disease (PD) and elucidating its underlying mechanisms using 6-hydroxydopamine (6-OHDA)-induced injury models. We found that $4 \mathrm{R}$ exhibited significant neuroprotective activity in the rat unilateral 6-OHDA-induced PD model in vivo. The therapeutic effect was evident both at morphological and behavioral levels. 4R (6 and $12 \mathrm{mg} / \mathrm{kg}$ ) treatments significantly improved outcomes of 6-OHDA-induced PD in vivo as indicated by reducing forelimb asymmetry scores and corner test scores 4 weeks after injection of 6-OHDA ( $p<$ 0.05). The therapeutic effect of $4 \mathrm{R}$ was also reflected by decreased depletion of tyrosine hydroxylase $(\mathrm{TH})$ in the striatum and substantia nigra (SN) on the side injected with 6OHDA. TH expression was 70.3 and $62.8 \%$ of the contralateral side in striatum and $\mathrm{SN}$, respectively, after $6 \mathrm{mg} / \mathrm{kg} 4 \mathrm{R}$ treatment; furthermore, it was 80.1 and $79.3 \%$ after treatment with $12 \mathrm{mg} / \mathrm{kg}$ of $4 \mathrm{R}$. In the control group, it was 51.9 and $23.6 \%$ of the contralateral striatum and SN $(p<0.05)$. Moreover, $4 \mathrm{R}$ also protected differentiated neuro-2a cells from 6-OHDA-induced cytotoxicity in vitro. The activation of $p$-AKT and HAX-1, and inhibition of caspase-3 and endothelial inflammation, were involved in 4R-mediated protection against 6-OHDA-induced injury. In conclusion, the present study indicates that $4 \mathrm{R}$ shows a therapeutic effect in the rat 6-OHDA-induced PD model in vivo and in 6-OHDA-challenged neuro-2a cells in vitro.

Keywords: cembranoid, inflammation, neuroprotection, caspase-3, tyrosine hydroxylase, Parkinson's disease, 6-OHDA 


\section{INTRODUCTION}

Parkinson's disease (PD) is the second most common neurodegenerative disease affecting more than one million people in the USA. It is estimated that 10 million people have PD worldwide (Foundation PsD., 2016). However, only a few pharmacological drugs are available for treating the symptoms of $\mathrm{PD}$ and none suppress the relentless progression of the disease. Some drugs like levodopa can lead to oxidative damage causing long-term side effects (Vijayakumar and Jankovic, 2016). Therefore, there is an urgent need for new therapeutics for PD.

Parkinson's disease is characterized by the progressive death of dopaminergic neurons in the pars compacta region of the substantia nigra (SN) and dopamine depletion in the striatum, which result in motor disability and postural abnormalities. Lewy bodies (LBs) and Lewy neurites (LNs) are the characteristics of pathological changes in $\mathrm{PD}$. The $\mathrm{LBs}$ and $\mathrm{LNs}$ in $\mathrm{PD}$ are mainly composed of the aggregated form of a presynaptic protein, $\alpha$-synuclein ( $\alpha$-Syn). $\alpha$-Syn aggregation and mutations of $\alpha$-Syn are associated with early-onset PD. In addition to the direct neurotoxicity of a-Syn, aggregation of the aberrant protein may also cause degeneration of dopaminergic neurons by inducing neuroinflammation (McGeer et al., 1988; Imamura et al., 2003). For instance, modification of the immune system in the a-Syn transduction PD model through knockout of proinflammatory-associated genes, such as MHCII, CX3CR1, or FccRIII, reduces M1/Th1 inflammatory reactions and protects dopaminergic neurons from degeneration (Harms et al., 2013). Although the pathophysiological mechanisms of PD remain poorly understood, it is well known that inflammation and apoptosis contribute to neurodegeneration in PD. Activation of microglia and release of inflammatory cytokines in the SN have been reported in PD patients (Langston et al., 1983; McGeer et al., 1988; Orr et al., 2002) and PD animal models (Akiyama and McGeer, 1989; Gao et al., 2002, 2003; McGeer et al., 2003). Endothelial inflammation and dysfunction were observed at the blood-brain barrier (BBB) in PD as well (Grammas et al., 2011). Inflammation at the level of the brain endothelium plays a role in the pathology of $\mathrm{PD}$ by triggering the release of various inflammatory cytokines, promoting recruitment of activated lymphocytes and monocytes into the brain, and activating microglia and other glial cells (Danton and Dietrich, 2003). Up-regulation of inflammatory mediators at the $\mathrm{BBB}$ is closely related to activation of nuclear factor kappa $\mathrm{B}(\mathrm{NF}-\kappa \mathrm{B})$, a master switch of inflammation (Baldwin, 2001; Keifer et al., 2001). Normally, NF- $\kappa \mathrm{B}$ is inactive by association with the inhibitor of NF- $\kappa$ B protein (I $\kappa$ B) in the cytosol (Jacobs and Harrison, 1998; Schwaninger et al., 2006). Upon activation, NF- $\kappa B$ is disassociated from $\mathrm{I} \kappa \mathrm{B}$ and is translocated into the nucleus, which leads to rapid up-regulation or down-regulation of its target gene expression. For example, elevated levels of endotoxin and proinflammatory cytokines increase NF- $\kappa \mathrm{B}$ activity leading to up-regulation of a variety of inflammatory mediators in brain endothelial cells, such as interleukin-1 (Quan et al., 1998a), tumor necrosis factor (TNF) (Nadeau and Rivest, 1999; Yang et al., 1999), cyclooxygenase-2 (Quan et al., 1998b), inducible nitric oxide synthase (Wong et al., 1996), and the adhesion molecules intercellular adhesion molecule 1 (ICAM-1) and vascular cell adhesion molecule 1 (VCAM-1) (Lindsberg et al., 1996; Henninger et al., 1997; Stanimirovic et al., 1997). The inflammation of the BBB leads to neuronal injury and death (de Vries et al., 1996), which may impact midbrain dopaminergic neurons, since these cells are more vulnerable to various insults (Gonzalez-Hernandez et al., 2010). Therefore, activation of NF$\kappa \mathrm{B}$ at the $\mathrm{BBB}$ is implicated in the development of PD (Hunot et al., 1997; Togo et al., 2001). It has been reported that NF$\kappa \mathrm{B}$ is also activated in dopaminergic neurons of PD patients and rodents administered the catecholaminergic neurotoxin 6hydroxydopamine (6-OHDA) (Hunot et al., 1997; Levites et al., 2002). These observations suggest that chronic inflammation may induce progressive neurodegeneration in the nigrostriatal system (McGeer et al., 2001; McGeer and McGeer, 2004).

There are also other mechanisms that contribute to neurodegeneration by triggering dopaminergic neuronal apoptosis in PD. One well-known mechanism is through inhibition of Akt, an anti-apoptotic protein, which plays an important role in neuroprotection. The Akt molecule is also called protein kinase B (PKB) with a structure similar to protein kinase A (PKA) (Staal, 1987; Cheng et al., 2005). Akt is the downstream kinase of phosphoinositide-3-kinase (PI3K). Over decades, the Akt pathway has been proven as an anti-apoptotic pathway, which is involved in cell survival and growth. As a survival kinase, Akt is activated by PI3K through phosphorylation. Recruitment of cytosolic Akt to the cell membrane via by phosphatidylinositol 1,3,5 triphosphate (PIP3) facilitates its phosphorylation and activation leading to neuronal survival (Namikawa et al., 2000; Alvarez-Tejado et al., 2001; Bijur and Jope, 2003; Leeds et al., 2005; Zhong et al., 2005). The p-Akt phosphorylates a number of apoptosis-regulatory molecules such as BAD, caspase 3 and 9, GSK-3 $\beta$, I $\mathrm{B}$ kinase, cAMP-responsive element binding protein (CREB), forkheads, and proline-rich Akt substrate (PRAS). Apoptotic functions of BAD, caspase 3 and 9, GSK-3 $\beta$, forkheads, and PRAS are inhibited, whereas antiapoptotic functions of CREB and Bcl-2 are activated by p-Akt (Chan, 2004; Harada et al., 2004; Fernandez-Gomez et al., 2006). Akt also works as a regulator to regulate cerebral blood flow by phosphorylation of eNOS in endothelial cells. The increased eNOS activity by Akt leads to an increase in cerebral blood flow (Lin et al., 2010). In addition to neuroprotection, Akt also plays an important role in neurogenesis. Neuronal differentiation and neurite outgrowth are essential during development of the nervous system and are crucial in neurogenesis. Akt has consistently been shown to have a positive influence on neuronal differentiation, neurite outgrowth, and neurite elongation in primary neurons (Kimura et al., 1994; Namikawa et al., 2000; Nakagomi et al., 2003; Tornieri et al., 2006; Tucker et al., 2006, 2008; Lim and Walikonis, 2008; Zheng et al., 2008). It has been shown that neurotrophins, such as nerve growth factor (NGF), brain-derived neurotrophic factor (BDNF) and neurotrophin-3 (NT3) promote neurogenesis by binding to Trk receptor tyrosine kinases, which then activate PI3K-Akt signal transduction (Huang and Reichardt, 2003). Importantly, research has shown that upregulation of Akt has a neuroprotective effect in PD (Hashimoto et al., 2004; Ries et al., 2006; Wu et al., 2007; 
Quesada et al., 2008; Yasuda et al., 2011). Therefore, upregulation of Akt could potentially be used alone or in combination with other therapeutic strategies to treat neurodegeneration in PD.

Another protein, hematopoietic lineage substrate-1associated protein X-1 (HAX-1), recently was found to have an anti-apoptotic function. HAX-1 has a structure similar to $\mathrm{Bcl}-2$ and is expressed in various tissues including brain and peripheral leukocytes (Hippe et al., 2006; Carlsson et al., 2008; Trebinska et al., 2010). HAX-1 interacts with a number of molecules, such as caspase-9 (Han et al., 2006), caspase-3 (Rami and Langhagen, 2012), heat-shock protein 90 (Lam et al., 2013), and mitochondrial proteases (Chao et al., 2008; Han et al., 2010), to regulate cell survival and growth. For instance, interactions between HAX-1 and mitochondrial proteases, including presenilins-associated rhomboid-like and high temperature-regulated $\mathrm{A} 2$ also known as Omi, are required to suppress cell apoptosis (Chao et al., 2008). A deficit of HAX-1 is associated with neuronal apoptosis and lymphocyte infiltration in the brain (Chao et al., 2008). Recent evidence indicates that HAX-1 is also involved in the development of the nervous system and pathologies of neurological diseases, such as ischemic stroke (Hao et al., 2008; Rami and Langhagen, 2012), brain trauma (Hao et al., 2008; Shi et al., 2011), and autosomal recessive severe congenital neutropenia (Klein et al., 2007; Rezaei et al., 2007; Carlsson et al., 2008; Ishikawa et al., 2008). Importantly, HAX-1-null mice have neurodegenerative parkinsonian features (Chao et al., 2008), which may indicate the involvement of HAX-1 deficit in the pathology of PD.

The present study focuses on the effect of $4 R$ on $P D$ and elucidating its underlying mechanisms using 6-OHDAinduced PD models in vitro and in vivo and a TNF- $\alpha$-induced inflammatory model in vitro. This study was designed to (i) evaluate the effect of $4 \mathrm{R}$ in the setting of 6-OHDA-induced experimental $\mathrm{PD}$ in the rat at the morphological and functional levels and (ii) elucidate its underlying mechanisms using in vitro $\mathrm{PD}$ and in vitro inflammatory models.

\section{METHODS}

\section{In vitro PD Model}

Neuro-2a cells, a mouse neural crest-derived cell line, purchased from ATCC (Manassas, VA, USA), were grown in DMEM with high glucose and L-glutamine (Hyclone, Logan, UT, USA) supplemented with $10 \%(\mathrm{v} / \mathrm{v})$ heat-inactivated fetal bovine serum (FBS) (Atlanta Bio Inc. GA, USA), and 1\% (v/v) 10,000 IU/ml penicillin $/ 10,000 \mathrm{mg} / \mathrm{ml}$ streptomycin (ATCC). Neuro-2a cells differentiate into dopaminergic cells in the presence of dibutyryl cyclic adenosine monophosphate (dbcAMP) and reduced serum. Briefly, cells were treated with dbcAMP at a final concentration of $2.5 \mathrm{mM}$ in the cell culture medium with $0.5 \%$ FBS for $72 \mathrm{~h}$ (Tremblay et al., 2010). Then, the cells were incubated with a 6-OHDA-ascorbic acid solution $(8,12.5$, or $25 \mu \mathrm{M}$ ) (SigmaAldrich Co. LLC., St. Louis, MO, USA) for $24 \mathrm{~h}$ to induce the neurotoxicity considered to be an in vitro PD model (Ochu et al., 1998; Storch et al., 2000). 4R (10, 20, or $50 \mathrm{nM})$ was added at the same time as 6-OHDA and incubated for $24 \mathrm{~h}$. $4 \mathrm{R}$ was prepared by Dr. K. El Sayed (School of Pharmacy, University of Louisiana, Monroe, LA) (El Sayed et al., 2008).

\section{In vitro Inflammatory Model}

The brain endothelial cell line (bEND5 cells) derived from mouse brain and immortalized with polyoma middle $\mathrm{T}$ oncogene was a generous gift from Dr. Ulrich Bickel, Texas Tech University. bEND5 cells were grown in DMEM media (Hyclone) supplemented with $10 \%(\mathrm{v} / \mathrm{v})$ FBS, $1 \mathrm{mM}$ sodium pyruvate, $4 \mathrm{mM}$ L-glutamine, $1 \%(\mathrm{v} / \mathrm{v})$ non-essential amino acids, $1 \%(\mathrm{v} / \mathrm{v})$ $10,000 \mathrm{IU} / \mathrm{ml}$ penicillin $/ 10,000 \mathrm{mg} / \mathrm{ml}$ streptomycin (all from ATCC). The inflammatory model was developed by stimulating bEND5 cells with $50 \mathrm{ng} / \mathrm{ml}$ TNF- $\alpha$ overnight (Tomita et al., 1998) and then treating with 4,8 , or $16 \mu \mathrm{M} 4 \mathrm{R}$ for $24 \mathrm{~h}$.

\section{Western Blot}

Cells were lysed in ice-cold 1X RIPA lysis buffer (Santa Cruz Biotechnology, Inc., CA, USA) containing: PMSF, sodium orthovanadate and protease inhibitor cocktail. After incubation in ice-cold buffer for $30 \mathrm{~min}$, the cell lysate was centrifuged at $10,000 \times \mathrm{g}$ for $10 \mathrm{~min}$ at $4^{\circ} \mathrm{C}$, and the supernatant was harvested. The detailed methods of the Western blot procedure were performed as previously described (Gao et al., 2003). The intensity of the chemiluminescence signal was normalized to that of $\beta$-actin as indicated. The following antibodies and the respective dilutions were used: 1:2,000 for $\beta$-actin, 1:2,000 for VCAM-1, 1:1,000 for cleaved caspase-3 and 1:2,000 for antirabbit secondary antibody (Cell Signaling Inc., Danvers, MA, USA); 1:1,000 for tyrosine hydroxylase (TH), 1:1,000 for p-Akt, 1:1,000 for ICAM-1 and 1:2,000 for anti-goat secondary antibody (Santa Cruz Biotechnology Inc.). The TATA box binding protein (TBP) was the nuclear protein loading control for p65. The antibody for TBP was from ABCAM and was used at 1:1,000 dilution.

\section{Adhesion Assay}

U937 cells (a monocyte cell line from ATCC) were cultured in RPMI 1640 medium (Hyclone) supplemented with $10 \%$ FBS, $2 \mathrm{mM}$ l-glutamine and $1 \%(\mathrm{v} / \mathrm{v}) 10,000 \mathrm{IU} / \mathrm{ml}$ penicillin $/ 10,000 \mathrm{mg} / \mathrm{ml}$ streptomycin (ATCC). All of the cell lines were maintained at $37^{\circ} \mathrm{C}, 5 \% \mathrm{CO}_{2}$, and $95 \%$ relative humidity. U937 cells were labeled with $5 \mathrm{mg} / \mathrm{mL}$ BCECF-AM (2N,7N-bis-(2carboxyethyl)-5-(and-6)-carboxyfluorescein), (Sigma Inc.) for $30 \mathrm{~min}$ at $37^{\circ} \mathrm{C}$, washed and re-suspended in serum-free media. bEND5 cells were cultured and incubated with $4 \mathrm{R}$ in a 24 -well plate for $8 \mathrm{~h}$ followed by $16 \mathrm{~h}$ of TNF- $\alpha(50 \mathrm{ng} / \mathrm{ml})$ stimulation, and then the cells were co-cultured with BCECF-AM-labeled U937 cells $\left(10^{6}\right.$ cells/well) for $30 \mathrm{~min}$ at $37^{\circ} \mathrm{C}$. Non-adhering U937 cells were removed, and cells were washed with phosphatebuffered saline (PBS), and then lysed in $0.1 \%$ Triton $\mathrm{X}-100$ in $0.1 \mathrm{M}$ Tris- $\mathrm{HCl}$ ( $\mathrm{pH}$ 7.4) (Sigma-Aldrich). Fluorescence (F) was measured with a microplate fluorescence reader (POLAR star OPTIMA, BMG Labtechnologies, Ortenberg, Germany) using excitation at $492 \mathrm{~nm}$ and emission at $535 \mathrm{~nm}$. The monocyte adhesion was calculated as Adhesion $(\%)=100 \times \mathrm{F}_{\text {sample }} / \mathrm{F}_{\text {total }}$ (fluorescence intensity of $10^{6}$ cells). The blank control group is the bEND5 cells without incubation of TNF-alpha. 


\section{MTT Assay}

Neuro-2a cells were cultured in a 96-well plate in serum-reduced medium with $2.5 \mathrm{mM}$ dbcAMP for $72 \mathrm{~h}$ to generate differentiated neuro-2a cells, dopaminergic-like cells. The differentiated neuro2a cells were co-incubated with different concentrations of 6$\operatorname{OHDA}(8,12.5$, and $25 \mu \mathrm{M})$ and either $4 \mathrm{R}(10,20$, and $50 \mathrm{nM})$ or DMSO (vehicle) for $24 \mathrm{~h}$. The protective effect of $4 \mathrm{R}$ on cell viability was measured by the 3-(4, 5-dimethylthiazol-2-yl)2, 5-diphenyltetrazolium bromide (MTT) assay. Briefly, MTT (Sigma-Aldrich) solution $(5 \mathrm{mg} / \mathrm{ml})$ was added $1: 10$ to the cell culture medium at $24 \mathrm{~h}$ after incubation with $4 \mathrm{R}$ or DMSO, and incubated for $2 \mathrm{~h}$ at $37^{\circ} \mathrm{C}$. Next, the medium was removed, and $200 \mu \mathrm{l}$ DMSO was added. The absorbance of the reaction product was measured in a plate reader at 570 and $690 \mathrm{~nm}$. OD background was subtracted from the $570 \mathrm{~nm}$ OD total signal.

\section{In vivo 6-OHDA PD Model}

All animal procedures were approved by the Institutional Animal Care and Use Committee at the University of Cincinnati and complied with pertinent NIH guidelines for care and use of animals. Sprague Dawley rats (body weight 200-300 g) supplied by Charles River (Wilmington, MA, USA) were kept under standardized light/dark $(12 \mathrm{~h})$, temperature $\left(22^{\circ} \mathrm{C}\right)$ and humidity (70\%) conditions, with rodent chow and water available. Rats were anesthetized with $100 \mathrm{mg} / \mathrm{kg}$ ketamine and $20 \mathrm{mg} / \mathrm{kg}$ xylazine (Butler Animal Health Supply Inc.) and positioned in a stereotaxic frame. To achieve a unilateral lesion of the nigrostriatal pathway, 6-OHDA was injected into two sites of the right striatum: AP: $+1.6 \mathrm{~mm}$; ML: $-2.4 \mathrm{~mm}$; DV: $-4.2 \mathrm{~mm}$; AP: $+0.2 \mathrm{~mm}$; ML: $-2.6 \mathrm{~mm}$; DV:-7.0 mm (Paxinos and Watson, 2007). The solution of $6-\mathrm{OHDA}(3 \mu \mathrm{g} / \mu \mathrm{l})$ was prepared in a $0.2 \%$ ascorbic acid saline. At each site, $2 \mu \mathrm{l}$ of 6-OHDA or vehicle was injected at a rate of $0.2 \mu \mathrm{l} / \mathrm{min}$ for $10 \mathrm{~min}$, with the needle left in place for $5 \mathrm{~min}$ before and after the injection. The final dosage of 6 -OHDA was $12 \mu \mathrm{g}$ per rat. $4 \mathrm{R}$ subcutaneous administration (6 or $12 \mathrm{mg} / \mathrm{kg}$ ) was started simultaneously with the striatal injection of 6-OHDA. Thereafter, $4 \mathrm{R}$ was administered every day for the first 3 days and then every other day for 4 weeks.

\section{Behavioral Tests}

The cylinder test was performed as previously described (Schallert et al., 2000; Hua et al., 2002; Hemmerle et al., 2014) to assess forelimb asymmetry every week after surgeries for 4 weeks. The rats were placed in an upright transparent cylinder, which encouraged vertical exploration of the walls using their forelimbs for weight support. The number of wall contacts made by each forelimb independent of the other or by both paws was scored for the calculation of limb usage asymmetry. Briefly, the asymmetry score was determined by the formula [(contralateral side $+1 / 2$ both)/(ipsilateral side + contralateral side + both)]. A ratio of 0.5 suggests equal usage of both limbs, whereas scores less than 0.5 indicate motor deficits in the contralateral limb.

The corner test was performed as described previously (Hao et al., 2008). The rat was placed between two boards at a $30^{\circ}$ angle facing the corner. Both sides of the vibrissae were stimulated when the rat reached deep into the corner, wherein the rat reared and turned either to the left or right to exit the corner. The 6OHDA-treated rats preferentially turn toward the non-impaired (right) side. Turns involving a rearing movement were scored. A total of 10 proper turns was recorded for each animal in each session. After baseline evaluation before surgery, the corner test was performed once per week for 4 weeks after injection of 6OHDA. The fraction of right turns out of the total number of turns served as the response variable.

\section{Immunohistochemistry and Stereology}

Rats were deeply anesthetized with a lethal dose of ketamine/xylazine and perfused intracardially with saline followed by $4 \%$ paraformaldehyde (PFA) (Sigma-Aldrich). Next, brains were dissected, post-fixed in PFA for $24 \mathrm{~h}$ and then placed in a $30 \%$ sucrose solution until they sunk. Brains were coronally sectioned at the striatal and ventral midbrain levels at $50-\mu \mathrm{m}$ thickness using a sliding microtome. For immunohistochemistry, free-floating brain sections were washed three times with phosphate buffer and incubated with $0.3 \%$ $\mathrm{H}_{2} \mathrm{O}_{2}$ for $10 \mathrm{~min}$. Next, the sections were treated with blocking buffer for $1 \mathrm{~h}$ and then incubated with $\mathrm{TH}$ primary antibody (Abcam; 1:200 dilution) in blocking buffer overnight in a humidified box at $4^{\circ} \mathrm{C}$. After washing with phosphate buffer, the sections were incubated with HRP-conjugated anti-rabbit secondary antibody for $1 \mathrm{~h}$ and stained with DAB kit reagents (Thermo Fisher Scientific). Four brain sections per animal were analyzed for $\mathrm{TH}$ immunostaining in STR and $\mathrm{SN}$, and the number of TH-positive cells was determined via unbiased stereological counting using Stereo Investigator (version 10.51) (West, 1993; Hemmerle et al., 2014). The contours were drawn at $2.5 \mathrm{X}$ and cell counting was performed at $60 \mathrm{X}$ using the optical fractionator. The sample sites were on a grid size of $170 \times 100$ for $\mathrm{TH}$ immunostaining with a guard zone set at $2.0 \mu \mathrm{m}$. The Gundersen correction was used to calculate the coefficient of error and was set at 0.10 or lower. The average absolute number of cells counted in the unlesioned (contralateral) SN was 800 cells/section. The optical densities of $\mathrm{TH}$ immunostaining in the striatum were determined via densitometric analysis using Scion Image (NIH).

\section{Statistical Analysis}

The outcomes of the $4 \mathrm{R}$-treated animals exposed to the PD model in vivo were compared to that of animals treated with vehicle (DMSO) and a sham lesion. Statistical significance was determined by one-way ANOVA followed by the Holm-Sidak test using Sigma plot version 12.5 from Systat Software, Inc.

\section{RESULTS}

\section{R Improves Behavioral and Morphological Outcomes of 6-OHDA-Induced Nigrostriatal Degeneration}

The scores for the cylinder test (forelimb asymmetry) and corner test for a normal rat should be 0.5 . If an asymmetry score is less than 0.5 or a corner test score is more than 0.5 , it indicates unilateral motor functional deficiency. The results showed that asymmetry scores were significantly lower than 0.5 , 

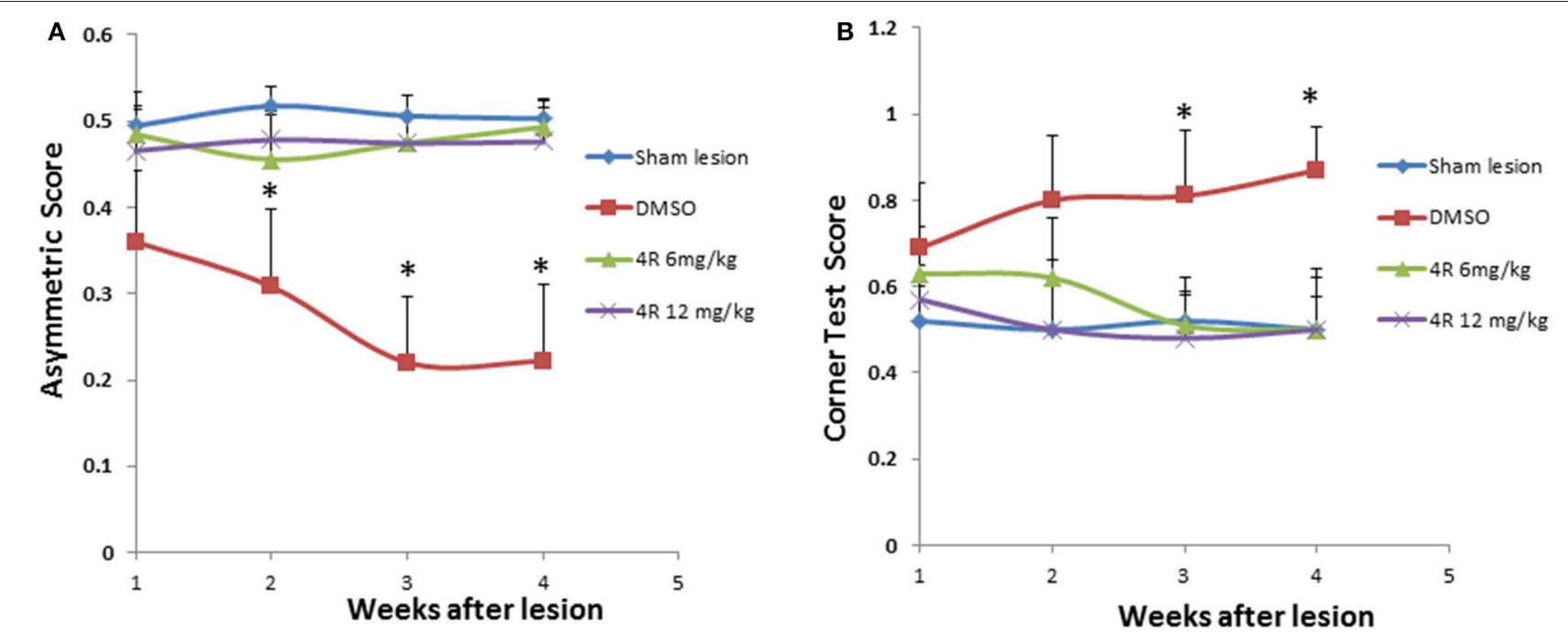

FIGURE 1 | The effect of 4R on the behavioral deficits of rats injected with 6-OHDA: (A) Asymmetry scores from the cylinder test, Mean \pm SD, $n=7,{ }^{\star} p<$ 0.05; (B) Corner test scores. Mean $\pm \mathrm{SD}, n=7,{ }^{*} p<0.05$. The sham lesion group was subjected to a sham surgical operation without injections into the striatum. DMSO is the vehicle control, in which DMSO was injected into the animals via subcutaneous injection. There are two $4 \mathrm{R}$ treatment groups, $4 \mathrm{R} 6 \mathrm{mg} / \mathrm{kg}$ and $4 \mathrm{R}$ $12 \mathrm{mg} / \mathrm{kg}$. The statistical analysis: ANOVA followed by the Holm-Sidak test.
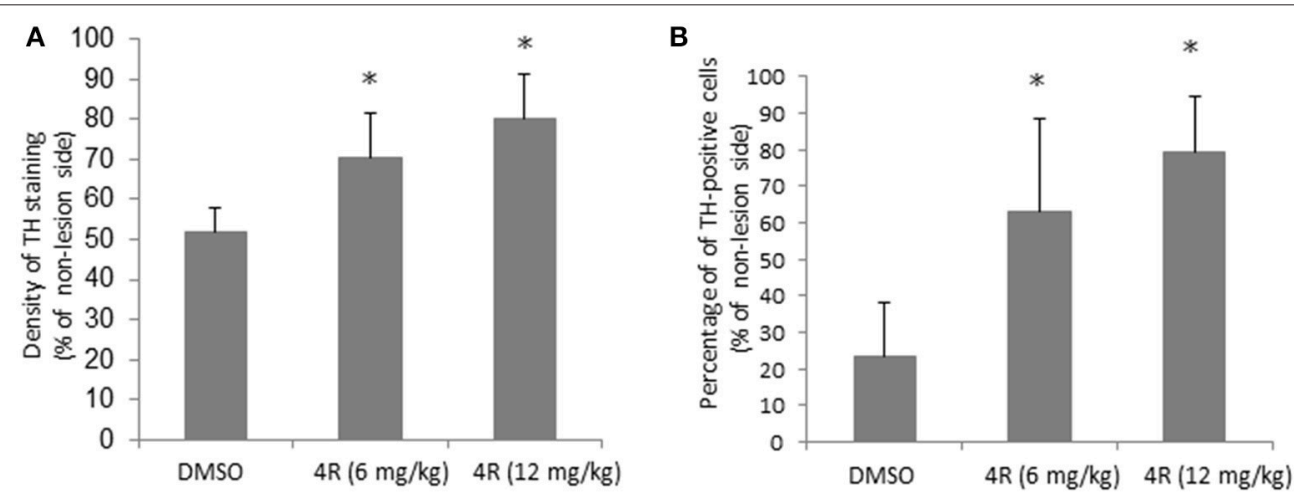

FIGURE 2 | The effect of 4R in TH immunostaining of the 6-OHDA-lesioned rats. (A) Quantification of the effect of $4 \mathrm{R}$ treatment on TH immunostaining in the striatum. (B) Quantification of the effect of $4 \mathrm{R}$ treatment on TH immunostaining in the SN. Mean $\pm \mathrm{SD}, n=7,{ }^{*} p<0.05$. The statistical analysis: ANOVA followed by the Holm-Sidak test.

and the corner test scores were significantly higher than 0.5 , after injection of 6-OHDA (pink curve in Figures 1A,B). The sham lesion did not have any effect on the scores of the behavioral tests (blue curve in Figure 1). However, treatment with both doses of $4 \mathrm{R}(6 \mathrm{mg} / \mathrm{kg}, 12 \mathrm{mg} / \mathrm{kg})$ significantly improved outcomes in the behavior tests: asymmetry scores and corner test scores were close to 0.5 during all 4 weeks after injection of 6-OHDA in animals co-treated with $4 \mathrm{R}$ (Figure 1).

As shown in Figure 1A, the asymmetry scores were 0.48 $\pm 0.05,0.46 \pm 0.05,0.47 \pm 0.03$, and $0.49 \pm 0.03$ in week1 , week-2, week-3, and week-4 after injection of $6 \mathrm{mg} / \mathrm{kg} 4 \mathrm{R}$, respectively; they were $0.47 \pm 0.05,0.48 \pm 0.03,0.47 \pm 0.03$, and $0.48 \pm 0.04$ in week-1, week- 2 , week-3, and week- 4 after injection of $12 \mathrm{mg} / \mathrm{kg} 4 \mathrm{R}$, respectively. As shown in Figure 1B, the corner test scores were $0.63 \pm 0.11,0.62 \pm 0.14,0.51 \pm$
0.08 , and $0.50 \pm 0.14$ in week-1, week-2, week-3, and week4 after injection of $6 \mathrm{mg} / \mathrm{kg} 4 \mathrm{R}$, respectively; they were 0.57 $\pm 0.08,0.50 \pm 0.12,0.48 \pm 0.14$, and $0.50 \pm 0.12$ in week1 , week-2, week-3, and week- 4 after injection of $12 \mathrm{mg} / \mathrm{kg} 4 \mathrm{R}$, respectively.

Furthermore, immunohistochemical evidence showed that the observed unilateral motor deficit was associated with 6OHDA-induced $\mathrm{TH}$ depletion in the nigrostriatal pathway. Compared to the contralateral side, there was a significant depletion of TH-positive fibers and cells on the lesion side in the right striatum and right $\mathrm{SN}$, respectively, after injection of 6-OHDA. The TH density and cell counts were $51.9 \pm 5.7 \%$ (Figure 2A) and $23.6 \pm 14.7 \%$ (Figure 2B) of the contralateral side in the right striatum and right $\mathrm{SN}$, respectively, in the DMSO vehicle group. However, both doses of $4 \mathrm{R}$ treatment 
A
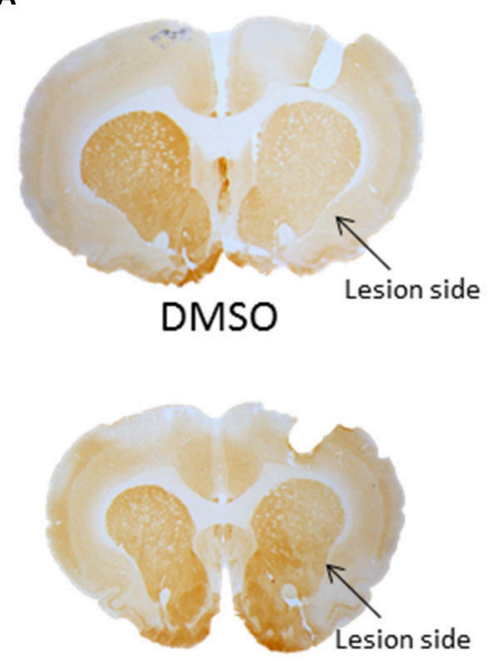

$6 \mathrm{mg} / \mathrm{kg}$ 4R Treatment

C

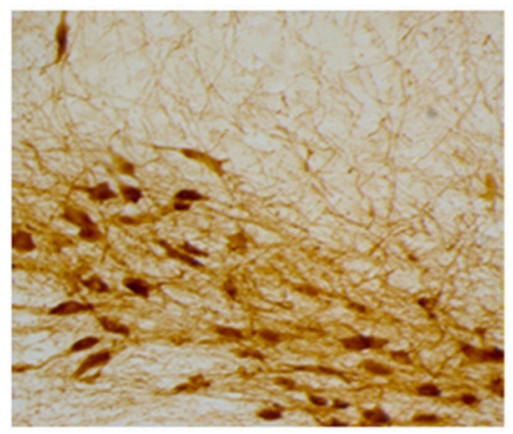

Contralateral side
B
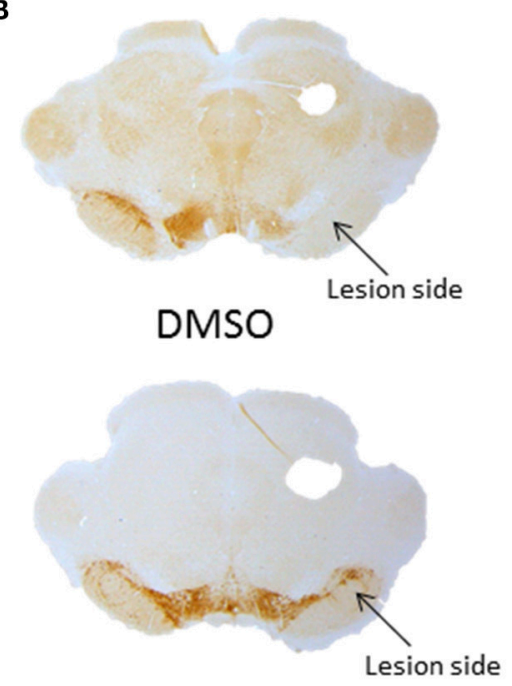

$6 \mathrm{mg} / \mathrm{kg} 4 \mathrm{R}$ Treatment

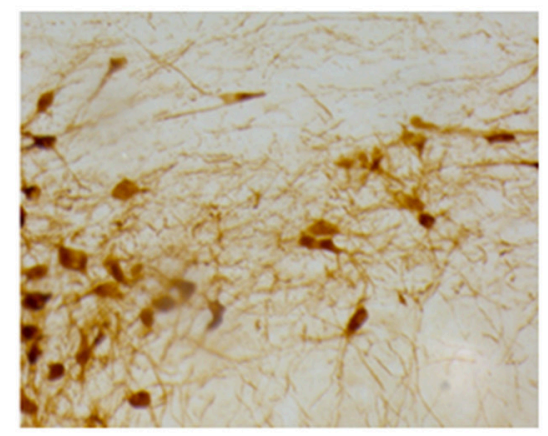

Lesion side

FIGURE 3 | (A) Images of TH immunostaining in the striatum. (B) Images of TH immunostaining in the SN. (C) High magnification mages of TH immunostaining in the $\mathrm{SN}$ of contralateral side (left) and of lesion side (right) of $6 \mathrm{mg} / \mathrm{kg}$-treated animal.

significantly attenuated $\mathrm{TH}$ depletion in both the striatum and $\mathrm{SN}$ of the lesioned side. TH expression was $70.3 \pm 11.3 \%$ (Figure 2A) and $62.8 \pm 25.8 \%$ (Figure 2B) of the contralateral side in the striatum and $\mathrm{SN}$, respectively, after $6 \mathrm{mg} / \mathrm{kg} 4 \mathrm{R}$ treatment; $\mathrm{TH}$ expression was $80.1 \pm 11 \%$ (Figure $2 \mathrm{~A}$ ) and 79.3 $\pm 15 \%$ (Figure $2 \mathrm{~B}$ ) of the contralateral side in the striatum and $\mathrm{SN}$, respectively, after $12 \mathrm{mg} / \mathrm{kg} 4 \mathrm{R}$ treatment (Figure 2B). Representative images of $\mathrm{TH}$ immunostaining are illustrated in Figure 3.

\section{R Protects Differentiated Neuro-2a Cells from 6-OHDA-Induced Cytotoxicity In vitro}

The viability of neuro-2a cells was decreased by 6-OHDA in a dose-dependent manner. Viability was reduced to $57.7 \pm$ $3.1,55.9 \pm 4.7$, and $36.7 \pm 6.2 \%$ of controls after incubation with $8,12.5$, and 256 -OHDA for $24 \mathrm{~h}$, respectively (Figure 4). Three doses of $4 \mathrm{R}(10,20$, and $50 \mathrm{nM})$ treatment significantly improved cell viability in all 6-OHDA-challenged groups. The cell viability was $82.5 \pm 3.5,82.1 \pm 2.8$, and $67.9 \pm 8.8 \%$ of control in $8 \mu \mathrm{M}$ 6-OHDA groups after 10,20 , and $50 \mathrm{nM} 4 \mathrm{R}$ treatment, respectively. The cell viability was $79.6 \pm 7.1,74.0 \pm$ 4.6 , and $75.6 \pm 6.1 \%$ of control in $12.5 \mu \mathrm{M}$ 6-OHDA groups after 10,20 , and $50 \mathrm{nM} 4 \mathrm{R}$ treatment, respectively. The cell viability was $52.6 \pm 2.0,57.8 \pm 9.0$, and $59.5 \pm 4.5 \%$ of control in $25 \mu \mathrm{M}$ 6-OHDA groups after 10, 20, and $50 \mathrm{nM} 4 \mathrm{R}$ treatment, respectively (Figure 4, $p<0.05$ ). The cellular signaling pathways involved in $4 \mathrm{R}$ protection were investigated. We found that antiapoptotic proteins such as p-AKT, HAX-1, and the apoptotic protein caspase-3, were involved in $4 \mathrm{R}$-mediated protection against 6-OHDA-induced injury. $25 \mu \mathrm{M}$ 6-OHDA significantly decreased phosphorylation of Akt and the expression of HAX1 in differentiated neuro-2a cells (Figures 5A,B). Conversely, there was an increase of cleaved caspase- 3 levels after incubation with 6-OHDA in the same samples (Figure 5C). Furthermore, $4 \mathrm{R}$ significantly increased the level of p-Akt (Figure 5A) and restored HAX-1 to base levels (Figure 5B). Simultaneously, 4R decreased the level of cleaved caspase- 3 induced by 6-OHDA (Figure 5C). 


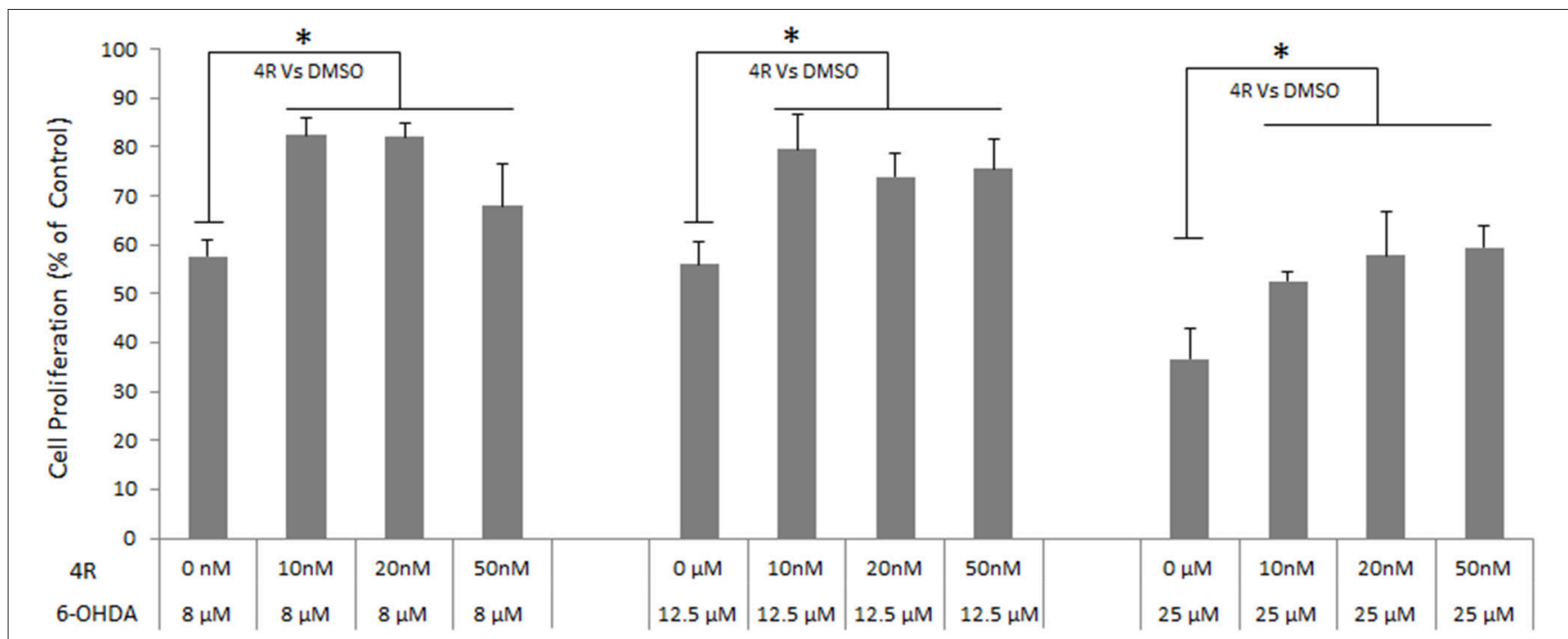

FIGURE 4 | The effect of different concentrations of $4 \mathrm{R}$ on the viability of differentiated neuro-2a cells in the in vitro PD model induced by several concentrations of 6-OHDA. Mean $\pm \mathrm{SD}, n=6,{ }^{*} p<0.05$.

\section{Effect of 4R on Endothelial Inflammation Induced by TNF- $\alpha$ in Murine Brain-Derived Endothelial Cells (bEND5 Cells)}

We studied the anti-inflammatory effect of $4 \mathrm{R}$ on TNF- $\alpha$ induced inflammation in brain-derived endothelial cells. TNF- $\alpha$ upregulated the expression of the nuclear NF- $\mathrm{B}$ subunit, p65, and the NF- $\kappa \mathrm{B}$-dependent inflammatory cytokine, VCAM-1, in the bEND5 cells. $4 \mathrm{R}$ attenuated the increased level of p65 and VCAM- 1 induced by TNF- $\alpha$ (Figures 5D,E). TNF- $\alpha$ dramatically increased the level of p 65 to $243 \pm 10 \%$ of controls. Treatment with $4 \mathrm{R}$ significantly reduced the level of p65 to $230 \pm 52,183$ \pm 24 , and $138 \pm 44 \%$ at concentrations of 4,8 , and $16 \mu \mathrm{M}$, respectively, suggesting that $4 \mathrm{R}$ blocked the nuclear translocation of NF- $\mathrm{B}$ in a dose-dependent manner (Figure 5D). VCAM-1 was expressed at a very low level under normal conditions, but TNF- $\alpha$ strongly induced its expression. However, the expression of VCAM-1 was significantly reduced to $93 \pm 19,76 \pm 13$, and $70 \pm 12 \%$ of TNF- $\alpha$-induced levels by $4 \mathrm{R}$ treatment at concentrations of 4,8 , and $16 \mu \mathrm{M}$, respectively (Figure 5E).

The adhesion of circulating monocytes to endothelial cells is an early step in inflammation. The monocyte adhesion assays with U-937 cells demonstrated the anti-inflammatory effects of $4 \mathrm{R}$ at the functional level. As shown in Figure $5 \mathrm{~F}$, when endothelial cells were stimulated by TNF- $\alpha$, the percentage of U937 cell adhesion to endothelial cells was increased to $26 \pm$ $0.021 \%$ compared to that in non-activated endothelial cells with $17 \pm 0.01 \%$ adherent monocytes. $4 \mathrm{R}$ treatment reduced the percentage of adherent U937 cells in a dose-dependent manner. The percentage of the adherent cells was $22 \pm 0.006,18 \pm 0.002$, $13 \pm 0.006 \%$ in 4,8 , and $16 \mu \mathrm{M} 4 \mathrm{R}$ treatments, respectively (Figure 5F). The results shown in Figures 5D-F indicate that $4 \mathrm{R}$ has anti-inflammatory activity, which most likely will have a beneficial effect on PD outcomes.

\section{DISCUSSION}

Some studies have indicated that exposure to tobacco reduces the risk of PD (Hernan et al., 2002; Gale and Martyn, 2003; Castagnoli and Murugesan, 2004; Chen et al., 2010; De Palma et al., 2010). One of the explanations for this observation is that nicotine exposure can promote dopaminergic neuron survival. However, there are many other compounds in tobacco leaves which could contribute to this protective effect. Cembranoids seem to be likely candidates for the neuroprotection exerted by tobacco. Cembranoid content in green leaves of tobacco is about $1 \%(\mathrm{w} / \mathrm{w})$ which is similar to the content of nicotine (13\%) (Hann et al., 1998; Ferchmin et al., 2001, 2009). 4R is the second most abundant cembranoid in tobacco plants. It is a stable, lipophilic small molecule (MW: 306) (Figure 6) that easily passes through the $\mathrm{BBB}$ reaching the brain. The concentration of $4 \mathrm{R}$ in the brain is higher than that of the plasma and remains in the brain for several hours (Velez-Carrasco et al., 2015). Brain-permeability of $4 \mathrm{R}$ was also evidenced by blockage of the central effect on behavioral sensitization to nicotine and inhibition of neuronal acetylcholine receptor (nAchR) function by intraperitoneal injection of $4 \mathrm{R}$ in rats (Ferchmin et al., 2001). The neuroprotective activity of $4 \mathrm{R}$ in hippocampal slices was shown to be mediated by the interaction between $\alpha 7$ and $\alpha 4 \beta 2$ nAChRs followed by activation of the PI3-kinase/Akt antiapoptotic cascade (Ferchmin et al., 2005, 2015). Furthermore, $4 \mathrm{R}$ was found to decrease the infarct size in mice and rats subjected to brain ischemia via inhibition of ICAM-1 expression and restoration of Akt phosphorylation (Martins et al., 2015).

The present results extend our previous findings regarding the neuroprotective effects of $4 \mathrm{R}$. We found that $4 \mathrm{R}$ significantly attenuated $\mathrm{TH}$ reduction induced by 6-OHDA in both the striatum and SN on the lesioned side of the animals (Figure 2). The loss of dopaminergic neurons in the $\mathrm{SN}$ and of $\mathrm{TH}$ 


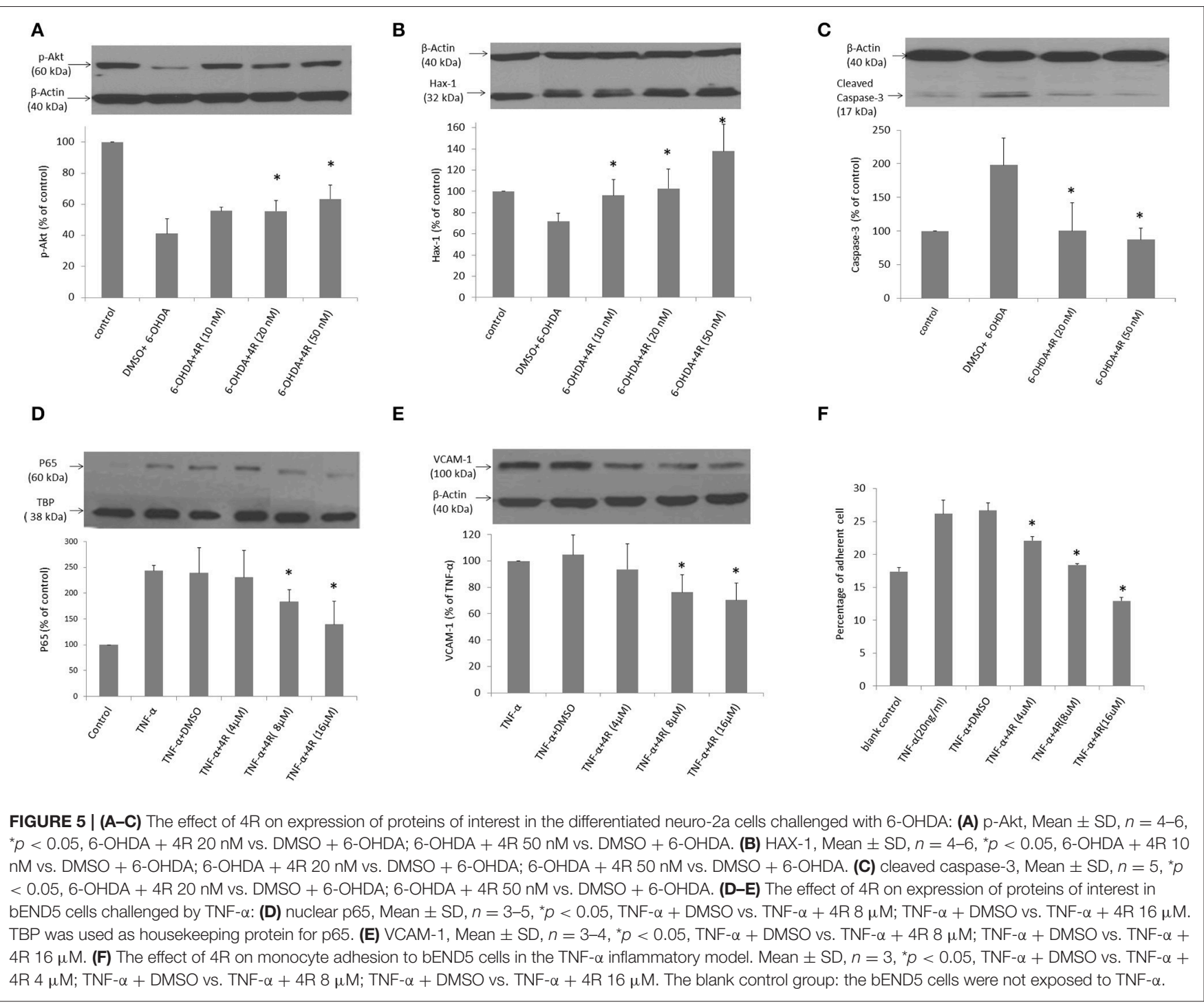

immunostaining in the striatum was reflected by corresponding functional deficits. The animals in the control groups performed worse over time in the behavior tests, reflecting the progressive loss of dopaminergic neurons; however, their behaviors were significantly improved in 4R-treatment groups in which both cylinder test and corner test scores were maintained close to the baseline (Figure 1). Furthermore, $4 \mathrm{R}$ was found to protect differentiated neuro-2a cells from 6-OHDA challenge (Figure 4), and this protection was associated with restoration of antiapoptotic protein p-Akt expression (Figure 5A). We also found neuroprotection of $4 \mathrm{R}$ in the neuro-2a cells was associated with enhancement of HAX-1 levels (Figure 5B). Besides effects of $4 \mathrm{R}$ on p-Akt and HAX-1 expression, the level of cleaved caspase- 3 was reduced by $4 \mathrm{R}$ treatment (Figure $5 \mathrm{C}$ ). The above observations indicate that neuroprotection of $4 \mathrm{R}$ was through maintaining and activating the anti-apoptotic proteins, Akt and HAX-1, which leads to inhibition of pro-apoptotic caspase-3 activity. In addition to neuroprotection, the anti-inflammatory effect of $4 \mathrm{R}$ may also contribute to its therapeutic effect in PD. As shown in Figures 5D-F, 4R suppressed the TNF- $\alpha$ induced monocyte adhesion to murine brain-derived endothelial cells by inhibiting expression of nuclear p65 and the NF$\kappa \mathrm{B}$ downstream inflammatory cytokine, VCAM-1. Monocyte adhesion is a functional indicator of the inflammatory response in vitro, and we used this assay to evaluate the effect of $4 \mathrm{R}$ on inflammation. 4R significantly inhibited U937 cell adhesion to the murine brain-derived endothelial cells (Figure 5F). These results are consistent with previous studies indicating antiinflammatory effects of cembranoids (Thao et al., 2014; Martins et al., 2015). Anti-inflammatory effects of $4 \mathrm{R}$ in brain-derived endothelial cells suggest that it may have anti-inflammatory effects in the $\mathrm{BBB}$ in vivo. The likely mechanism of the antiinflammatory effects of $4 \mathrm{R}$ is via inhibition of NF-kB activity in the endothelial cells, which leads to a reduction of its downstream inflammatory cytokines, including VCAM-1 and ICAM-1. Therefore, the anti-inflammatory effect of $4 \mathrm{R}$ on brain 


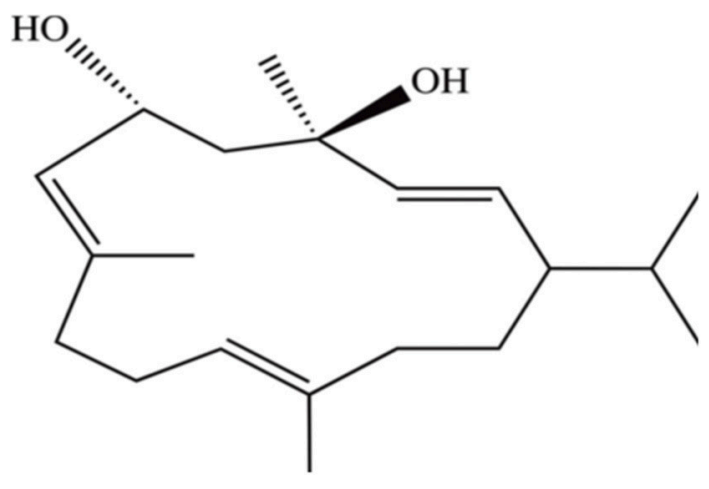

FIGURE 6 | The structure of 4R.

endothelial cells may provide additional protection for neurons against injury induced by various insults like ischemia and 6OHDA. Notably, because $4 \mathrm{R}$ can pass through the BBB and access the brain, $4 \mathrm{R}$ may also have similar effects on microglia, which could contribute to its therapeutic effect in PD. Further study will be needed to elucidate 4 R's effect on microglia.

In summary, previous studies have found that $4 \mathrm{R}$ has neuroprotective effects against acute injury induced by $\mathrm{N}$ methyl-D-aspartate (NMDA), ischemia or organophosphorus compounds (Ferchmin et al., 2005, 2014; Eterovic et al., 2011, 2013; Martins et al., 2015). Our current study found that $4 \mathrm{R}$ has therapeutic effects in the rat 6-OHDA progressive PD model, which is a chronic injury. The present results are consistent with the following conclusions: First, $4 \mathrm{R}$ has significant neuroprotective activity in both the rat 6-OHDAinduced PD model in vivo and 6-OHDA-induced injury in differentiated neuro-2a cells in vitro. The therapeutic effect in the rat $\mathrm{PD}$ model is evident both at morphological and behavioral levels. Second, 4R's neuroprotection is associated with activation of the anti-apoptotic proteins Akt and HAX-1, and inhibition of vascular inflammation by inhibition of NF- $\mathrm{KB}$ activity. However, it is not known at this point if activation of Akt and HAX-1 are the consequences of the anti-inflammatory effect of $4 \mathrm{R}$ or a direct effect of $4 \mathrm{R}$ on these two proteins. The present findings may also provide new insight regarding the reduced risk for $\mathrm{PD}$ among cigarette smokers, which may have benefited from $4 \mathrm{R}$ in the tobacco, whereas it was traditionally thought to be mediated only by nicotine. Although the present results demonstrate the therapeutic efficacy of $4 \mathrm{R}$ in a model of $\mathrm{PD}$ in vivo when the drug

\section{REFERENCES}

Chen, H., Huang, X., Guo, X., Mailman, R. B., Park, Y., Kamel, F., et al. (2010). Smoking duration, intensity, and risk of Parkinson disease. Neurology 74, 878-884. doi: 10.1212/WNL.0b013e3181d55f38

Akiyama, H., and McGeer, P. L. (1989). Microglial response to 6hydroxydopamine-induced substantia nigra lesions. Brain Res. 489, 247-253. doi: 10.1016/0006-8993(89)90857-3

Alvarez-Tejado, M., Naranjo-Suarez, S., Jimenez, C., Carrera, A. C., Landazuri, M. O., and del Peso, L. (2001). Hypoxia induces the activation of the phosphatidylinositol 3-kinase/Akt cell survival pathway in PC12 was administered just after injection of 6-OHDA, the duration of the therapeutic window remains to be determined in future experiments. Furthermore, it is necessary to perform additional mechanistic studies in vivo to elucidate the mechanism(s) of action of 4R's therapeutic effect in PD. A previous study has indicated that $4 \mathrm{R}$ has no toxicity at the high concentration of $30 \mathrm{mg} / \mathrm{kg}$ in rats and $4 \mathrm{R}$ easily passes through BBB (VelezCarrasco et al., 2015). 4R, or one of its analogs, is likely to have an impact on PD therapy and open the door for novel applications of tobacco products for medical purposes. Accordingly, the present study may provide new lead compounds for the development of novel therapeutic agents for PD.

\section{ETHICS STATEMENT}

All protocols involving the use of live rats were revised and approved by the Institutional Animal Care and Use Committee of the James L. Winkle College of Pharmacy, University of Cincinnati.

\section{AUTHOR CONTRIBUTIONS}

JHu: Performed experiments, data acquisition, analysis and interpretation of data. Drafted manuscript. AH: Assisted in establishing the PD model; assisted with the stereology; revised the manuscript. KBS: Participated in setting up PD model. Revised the manuscript. VE: Participated in data analysis and interpretation. Revised the manuscript. PF: Drafted and revised the manuscript. Contributed to analysis, and interpretation of data. Provided the $4 \mathrm{R}$ for the study. JHao: Designed the study, analyzed and interpreted the data. Drafted the manuscript; approved the final version to be published.

\section{ACKNOWLEDGMENTS}

We acknowledge the intellectual contribution of Khalid El Sayed involved in the preparation of $4 \mathrm{R}$. This work was supported by the Michael J. Fox Foundation for Parkinson's Research 2012 RAPID RESPONSE INNOVATION AWARDS, (JHao), NIHU54NS083924 to V.A. Eterovic U.C.Caribe, The James L. Winkle College of Pharmacy new faculty start-up funding (JHao), the Gardner Family Center for Parkinson's Disease and Movement Disorders (KBS) and the Selma Schottenstein Harris Lab for Research in Parkinson's Disease (KBS). 
associated with specific HAX1 mutations. J. Intern. Med. 264, 388-400. doi: 10.1111/j.1365-2796.2008.01982.x

Castagnoli, K., and Murugesan, T. (2004). Tobacco leaf, smoke and smoking, MAO inhibitors, Parkinson's disease and neuroprotection; are there links? Neurotoxicology 25, 279-291. doi: 10.1016/S0161-813X(03)00107-4

Chan, P. H. (2004). Future targets and cascades for neuroprotective strategies. Stroke 35(11 Suppl. 1), 2748-2750. doi: 10.1161/01.STR.0000143325.25610.ac

Chao, J. R., Parganas, E., Boyd, K., Hong, C. Y., Opferman, J. T., and Ihle, J. N. (2008). Hax1-mediated processing of HtrA2 by Parl allows survival of lymphocytes and neurons. Nature 452, 98-102. doi: 10.1038/nature06604

Cheng, J. Q., Lindsley, C. W., Cheng, G. Z., Yang, H., and Nicosia, S. V. (2005). The Akt/PKB pathway: molecular target for cancer drug discovery. Oncogene 24, 7482-7492. doi: 10.1038/sj.onc.1209088

Danton, G. H., and Dietrich, W. D. (2003). Inflammatory mechanisms after ischemia and stroke. J. Neuropathol. Exp. Neurol. 62, 127-136. doi: 10.1093/jnen/62.2.127

De Palma, G., Dick, F. D., Calzetti, S., Scott, N. W., Prescott, G. J., Osborne, A., et al. (2010). A case-control study of Parkinson's disease and tobacco use: gene-tobacco interactions. Mov. Dis. 25, 912-919. doi: 10.1002/mds.22980

de Vries, H. E., Blom-Roosemalen, M. C., de Boer, A. G., van Berkel, T. J., Breimer, D. D., and Kuiper, J. (1996). Effect of endotoxin on permeability of bovine cerebral endothelial cell layers in vitro. J. Pharmacol. Exp. Ther. 277, 1418-1423.

El Sayed, K. A., Laphookhieo, S., Baraka, H. N., Yousaf, M., Hebert, A., Bagaley, D., et al. (2008). Biocatalytic and semisynthetic optimization of the antiinvasive tobacco (1S,2E,4R,6R,7E,11E)-2,7,11-cembratriene-4,6-diol. Bioorg. Med. Chem. 16, 2886-2893. doi: 10.1016/j.bmc.2007.12.056

Eterovic, V. A., Del Valle-Rodriguez, A., Perez, D., Carrasco, M., Khanfar, M. A., El Sayed, K. A., et al. (2013). Protective activity of (1S,2E,4R,6R,7E,11E)2,7,11-cembratriene-4,6-diol analogues against diisopropylfluorophosphate neurotoxicity: preliminary structure-activity relationship and pharmacophore modeling. Bioorg. Med. Chem. 21, 4678-4686. doi: 10.1016/j.bmc.2013.05.018

Eterovic, V. A., Perez, D., Martins, A. H., Cuadrado, B. L., Carrasco, M., and Ferchmin, P. A. (2011). A cembranoid protects acute hippocampal slices against paraoxon neurotoxicity. Toxicol. In Vitro 25, 1468-1474. doi: 10.1016/j.tiv.2011.04.021

Ferchmin, P. A., Andino, M., Reyes Salaman, R., Alves, J., VelezRoman, J., Cuadrado, B., et al. (2014). 4R-cembranoid protects against diisopropylfluorophosphate-mediated neurodegeneration. Neurotoxicology 44 , 80-90. doi: 10.1016/j.neuro.2014.06.001

Ferchmin, P. A., Hao, J., Perez, D., Penzo, M., Maldonado, H. M., Gonzalez, M. T., et al. (2005). Tobacco cembranoids protect the function of acute hippocampal slices against NMDA by a mechanism mediated by $\alpha 4 \beta 2$ nicotinic receptors. J. Neurosci. Res. 82, 631-641. doi: 10.1002/jnr.20666

Ferchmin, P. A., Lukas, R. J., Hann, R. M., Fryer, J. D., Eaton, J. B., Pagan, O. R., et al. (2001). Tobacco cembranoids block behavioral sensitization to nicotine and inhibit neuronal acetylcholine receptor function. J. Neurosci. Res. 64, 18-25. doi: 10.1002/jnr.1049

Ferchmin, P. A., Pagan, O. R., Ulrich, H., Szeto, A. C., Hann, R. M., and Eterovic, V. A. (2009). Actions of octocoral and tobacco cembranoids on nicotinic receptors. Toxicon 54, 1174-1182. doi: 10.1016/j.toxicon.2009. 02.033

Ferchmin, P. A., Perez, D., Castro Alvarez, W., Penzo, M. A., Maldonado, H. M., and Eterovic, V. A. (2015). gamma-Aminobutyric acid type A receptor inhibition triggers a nicotinic neuroprotective mechanism. J. Neurosci. Res. 91, 416-425. doi: 10.1002/jnr.23155

Fernandez-Gomez, F. J., Pastor, M. D., Garcia-Martinez, E. M., MeleroFernandez de Mera, R., Gou-Fabregas, M., Gomez-Lazaro, M., et al. (2006). Pyruvate protects cerebellar granular cells from 6-hydroxydopamineinduced cytotoxicity by activating the Akt signaling pathway and increasing glutathione peroxidase expression. Neurobiol. Dis. 24, 296-307. doi: 10.1016/j.nbd.2006.07.005

Foundation PsD. (2016). Parkinson's Disease Foundation. Available online at: http://www.pdf.org/en/parkinson_statistics

Gale, C., and Martyn, C. (2003). Tobacco, coffee, and Parkinson's disease. BMJ 326, 561-562. doi: 10.1136/bmj.326.7389.561

Gao, H. M., Hong, J. S., Zhang, W., and Liu, B. (2002). Distinct role for microglia in rotenone-induced degeneration of dopaminergic neurons. J. Neurosci. 22, 782-790. Available online at: http://www.jneurosci.org/content/22/3/782
Gao, H. M., Liu, B., Zhang, W., and Hong, J. S. (2003). Novel antiinflammatory therapy for Parkinson's disease. Trends Pharmacol. Sci. 24, 395-401. doi: 10.1016/S0165-6147(03)00176-7

Gonzalez-Hernandez, T., Cruz-Muros, I., Afonso-Oramas, D., Salas-Hernandez, J., and Castro-Hernandez, J. (2010). Vulnerability of mesostriatal dopaminergic neurons in Parkinson's disease. Front. Neuroanat. 4:140. doi: 10.3389/fnana.2010.00140

Grammas, P., Martinez, J., and Miller, B. (2011). Cerebral microvascular endothelium and the pathogenesis of neurodegenerative diseases. Expert Rev. Mol. Med. 13:e19. doi: 10.1017/S1462399411001918

Han, J., Goldstein, L. A., Hou, W., Froelich, C. J., Watkins, S. C., and Rabinowich, H. (2010). Deregulation of mitochondrial membrane potential by mitochondrial insertion of granzyme B and direct Hax-1 cleavage. J. Biol. Chem. 285, 22461-22472. doi: 10.1074/jbc.M109.086587

Han, Y., Chen, Y. S., Liu, Z., Bodyak, N., Rigor, D., Bisping, E., et al. (2006). Overexpression of HAX-1 protects cardiac myocytes from apoptosis through caspase-9 inhibition. Circ. Res. 99, 415-423. doi: 10.1161/01.RES.0000237387.05259.a5

Hann, R. M., Pagan, O. R., Gregory, L., Jacome, T., Rodriguez, A. D., Ferchmin, P. A., et al. (1998). Characterization of cembranoid interaction with the nicotinic acetylcholine receptor. J. Pharmacol. Exp. Ther. 287, 253-260.

Hao, J., Mdzinarishvili, A., Abbruscato, T. J., Klein, J., Geldenhuys, W. J., Van der Schyf, C. J., et al. (2008). Neuroprotection in mice by NGP1-01 after transient focal brain ischemia. Brain Res. 1196, 113-120. doi: 10.1016/j.brainres.2007.11.075

Harada, N., Hatano, E., Koizumi, N., Nitta, T., Yoshida, M., Yamamoto, N., et al. (2004). Akt activation protects rat liver from ischemia/reperfusion injury. J. Surg. Res. 121, 159-170. doi: 10.1016/j.jss.2004.04.016

Harms, A. S., Cao, S., Rowse, A. L., Thome, A. D., Li, X., Mangieri, L. R., et al. (2013). MHCII is required for alpha-synuclein-induced activation of microglia, CD4 T cell proliferation, and dopaminergic neurodegeneration. J. Neurosci. 33, 9592-9600. doi: 10.1523/JNEUROSCI.5610-12.2013

Hashimoto, M., Bar-On, P., Ho, G., Takenouchi, T., Rockenstein, E., Crews, L., et al. (2004). $\beta$-synuclein regulates Akt activity in neuronal cells. A possible mechanism for neuroprotection in Parkinson's disease. J. Biol. Chem. 279, 23622-23629. doi: 10.1074/jbc.M313784200

Hemmerle, A. M., Dickerson, J. W., Herman, J. P., and Seroogy, K. B. (2014). Stress exacerbates experimental Parkinson/'s disease. Mol. Psychiatry. 19, 638-640. doi: $10.1038 / \mathrm{mp} .2013 .108$

Henninger, D. D., Panes, J., Eppihimer, M., Russell, J., Gerritsen, M., Anderson, D. C., et al. (1997). Cytokine-induced VCAM-1 and ICAM-1 expression in different organs of the mouse. J. Immunol. 158, 1825-1832.

Hernan, M. A., Takkouche, B., Caamano-Isorna, F., and Gestal-Otero, J. J. (2002). A meta-analysis of coffee drinking, cigarette smoking, and the risk of Parkinson's disease. Ann. Neurol. 52, 276-284. doi: 10.1002/ana.10277

Hippe, A., Bylaite, M., Chen, M., von Mikecz, A., Wolf, R., Ruzicka, T., et al. (2006). Expression and tissue distribution of mouse Haxl. Gene 379, 116-126. doi: $10.1016 /$ j.gene.2006.04.027

Hua, Y., Schallert, T., Keep, R. F., Wu, J., Hoff, J. T., and Xi, G. (2002). Behavioral tests after intracerebral hemorrhage in the rat. Stroke 33, 2478-2484 doi: 10.1161/01.STR.0000032302.91894.0F

Huang, E. J., and Reichardt, L. F. (2003). Trk receptors: roles in neuronal signal transduction. Annu. Rev. Biochem. 72, 609-642. doi: 10.1146/annurev.biochem.72.121801.161629

Hunot, S., Brugg, B., Ricard, D., Michel, P. P., Muriel, M. P., Ruberg, M., et al. (1997). Nuclear translocation of NF- $\mathrm{kB}$ is increased in dopaminergic neurons of patients with parkinson disease. Proc. Natl. Acad. Sci. U.S.A. 94, 7531-7536. doi: $10.1073 /$ pnas.94.14.7531

Imamura, K., Hishikawa, N., Sawada, M., Nagatsu, T., Yoshida, M., and Hashizume, Y. (2003). Distribution of major histocompatibility complex class II-positive microglia and cytokine profile of Parkinson's disease brains. Acta Neuropathol. 106, 518-526. doi: 10.1007/s00401-003-0766-2

Ishikawa, N., Okada, S., Miki, M., Shirao, K., Kihara, H., Tsumura, M., et al. (2008). Neurodevelopmental abnormalities associated with severe congenital neutropenia due to the R86X mutation in the HAX1 gene. J. Med. Genet. 45, 802-807. doi: $10.1136 /$ jmg.2008.058297

Jacobs, M. D., and Harrison, S. C. (1998). Structure of an IкB $\alpha / N F-\kappa B$ complex. Cell 95, 749-758. doi: 10.1016/S0092-8674(00)81698-0 
Keifer, J. A., Guttridge, D. C., Ashburner, B. P., and Baldwin, A. S. Jr. (2001). Inhibition of NF-kappa B activity by thalidomide through suppression of IkappaB kinase activity. J. Biol. Chem. 276, 22382-22387. doi: 10.1074/jbc.M100938200

Kimura, K., Hattori, S., Kabuyama, Y., Shizawa, Y., Takayanagi, J., Nakamura, S., et al. (1994). Neurite outgrowth of PC12 cells is suppressed by wortmannin, a specific inhibitor of phosphatidylinositol 3-kinase. J. Biol. Chem. 269, 18961-18967.

Klein, C., Grudzien, M., Appaswamy, G., Germeshausen, M., Sandrock, I., Schaffer, A. A., et al. (2007). HAX1 deficiency causes autosomal recessive severe congenital neutropenia (Kostmann disease). Nat. Genet. 39, 86-92. doi: $10.1038 /$ ng 1940

Lam, C. K., Zhao, W., Cai, W., Vafiadaki, E., Florea, S. M., Ren, X., et al. (2013). Novel role of HAX-1 in ischemic injury protection involvement of heat shock protein 90. Circ. Res. 112, 79-89. doi: 10.1161/CIRCRESAHA.112.279935

Langston, J. W., Ballard, P., Tetrud, J. W., and Irwin, I. (1983). Chronic Parkinsonism in humans due to a product of meperidine-analog synthesis. Science 219, 979-980. doi: 10.1126/science.6823561

Leeds, P., Leng, Y., Chalecka-Franaszek, E., and Chuang, D. M. (2005). Neurotrophins protect against cytosine arabinoside-induced apoptosis of immature rat cerebellar neurons. Neurochem. Int. 46, 61-72. doi: 10.1016/j.neuint.2004.07.001

Levites, Y., Youdim, M. B., Maor, G., and Mandel, S. (2002). Attenuation of 6-hydroxydopamine (6-OHDA)-induced nuclear factor-kappaB (NF-кB) activation and cell death by tea extracts in neuronal cultures. Biochem. Pharmacol. 63, 21-29. doi: 10.1016/S0006-2952(01)00813-9

Lim, C. S., and Walikonis, R. S. (2008). Hepatocyte growth factor and c-Met promote dendritic maturation during hippocampal neuron differentiation via the Akt pathway. Cell. Signal. 20, 825-835. doi: 10.1016/j.cellsig.2007.12.013

Lin, H. Y., Wu, C. L., and Huang, C. C. (2010). The Akt-endothelial nitric oxide synthase pathway in lipopolysaccharide preconditioning-induced hypoxic-ischemic tolerance in the neonatal rat brain. Stroke 41, 1543-1551. doi: 10.1161/STROKEAHA.109.574004

Lindsberg, P. J., Carpen, O., Paetau, A., Karjalainen-Lindsberg, M. L., and Kaste, M. (1996). Endothelial ICAM-1 expression associated with inflammatory cell response in human ischemic stroke. Circulation 94, 939-945. doi: 10.1161/01.CIR.94.5.939

Martins, A. H., Hu, J., Xu, Z., Mu, C., Alvarez, P., Ford, B. D., et al. (2015). Neuroprotective activity of (1S,2E,4R,6R,-7E,11E)-2,7,11-cembratriene-4,6diol (4R) in vitro and in vivo in rodent models of brain ischemia. Neuroscience 291, 250-259. doi: 10.1016/j.neuroscience.2015.02.001

McGeer, P. L., Itagaki, S., Boyes, B. E., and McGeer, E. G. (1988). Reactive microglia are positive for HLA-DR in the substantia nigra of Parkinson's and Alzheimer's disease brains. Neurology 38, 1285-1291. doi: 10.1212/WNL.38.8.1285

McGeer, P. L., and McGeer, E. G. (2004). Inflammation and neurodegeneration in Parkinson's disease. Parkinsonism Relat. Disord. 10(Suppl. 1), S3-S7. doi: 10.1016/j.parkreldis.2004.01.005

McGeer, P. L., Schwab, C., Parent, A., and Doudet, D. (2003). Presence of reactive microglia in monkey substantia nigra years after 1-methyl-4phenyl-1,2,3,6-tetrahydropyridine administration. Ann. Neurol. 54, 599-604. doi: 10.1002/ana.10728

McGeer, P. L., Yasojima, K., and McGeer, E. G. (2001). Inflammation in Parkinson's disease. Adv. Neurol. 86, 83-89.

Nadeau, S., and Rivest, S. (1999). Regulation of the gene encoding tumor necrosis factor alpha (TNF- $\alpha$ ) in the rat brain and pituitary in response in different models of systemic immune challenge. J. Neuropathol. Exp. Neurol. 58, 61-77. doi: 10.1097/00005072-199901000-00008

Nakagomi, S., Suzuki, Y., Namikawa, K., Kiryu-Seo, S., and Kiyama, H. (2003). Expression of the activating transcription factor 3 prevents c-Jun $\mathrm{N}$-terminal kinase-induced neuronal death by promoting heat shock protein 27 expression and Akt activation. I. Neurosci. 23, 5187-5196.

Namikawa, K., Honma, M., Abe, K., Takeda, M., Mansur, K., Obata, T., et al. (2000). Akt/protein kinase B prevents injury-induced motoneuron death and accelerates axonal regeneration. J. Neurosci.. 20, 2875-2886. Available online at: http://www.jneurosci.org/content/20/8/2875

Ochu, E. E., Rothwell, N. J., and Waters, C. M. (1998). Caspases mediate 6-hydroxydopamine-induced apoptosis but not necrosis in PC12 cells. J. Neurochem. 70, 2637-2640. doi: 10.1046/j.1471-4159.1998.70062637.x
Orr, C. F., Rowe, D. B., and Halliday, G. M. (2002). An inflammatory review of Parkinson's disease. Prog. Neurobiol. 68, 325-340. doi: 10.1016/S0301-0082(02)00127-2

Paxinos, G., and Watson, C. (2007). The Rat Brain in Stereotaxic Coordinates/George Paxinos, Charles Watson. New York, NY: Academic Press.

Quan, N., Whiteside, M., and Herkenham, M. (1998a). Time course and localization patterns of interleukin-1 $\beta$ messenger RNA expression in brain and pituitary after peripheral administration of lipopolysaccharide. Neuroscience 83, 281-293. doi: 10.1016/S0306-4522(97)00350-3

Quan, N., Whiteside, M., and Herkenham, M. (1998b). Cyclooxygenase 2 mRNA expression in rat brain after peripheral injection of lipopolysaccharide. Brain Res. 802, 189-197. doi: 10.1016/S0006-8993(98)00402-8

Quesada, A., Lee, B. Y., and Micevych, P. E. (2008). PI3 kinase/Akt activation mediates estrogen and IGF-1 nigral DA neuronal neuroprotection against a unilateral rat model of Parkinson's disease. Dev. Neurobiol. 68, 632-644. doi: 10.1002/dneu.20609

Rami, A., and Langhagen, A. (2012). Specific alterations of the HtrA2/HAX-1 ratio in the penumbra upon focal cerebral ischemia in mice. Neurochem. Res. 37, 548-556. doi: 10.1007/s11064-011-0641-9

Rezaei, N., Chavoshzadeh, Z., Alaei, O. R., Sandrock, I., and Klein, C. (2007). Association of HAX1 deficiency with neurological disorder. Neuropediatrics 38 , 261-263. doi: 10.1055/s-2008-1062704

Ries, V., Henchcliffe, C., Kareva, T., Rzhetskaya, M., Bland, R., During, M. J., et al. (2006). Oncoprotein Akt/PKB induces trophic effects in murine models of Parkinson's disease. Proc. Natl. Acad. Sci. U.S.A. 103, 18757-18762. doi: 10.1073/pnas.0606401103

Schallert, T., Fleming, S. M., Leasure, J. L., Tillerson, J. L., and Bland, S. T. (2000). CNS plasticity and assessment of forelimb sensorimotor outcome in unilateral rat models of stroke, cortical ablation, parkinsonism and spinal cord injury. Neuropharmacology 39, 777-787. doi: 10.1016/S0028-3908(00)00005-8

Schwaninger, M., Inta, I., and Herrmann, O. (2006). NF-kappaB signalling in cerebral ischaemia. Biochem. Soc. Trans. 34(Pt 6), 1291-1294. doi: 10.1042/BST0341291

Shi, W., Zhao, W., Shen, A., Shao, B., Wu, X., Yang, J., et al. (2011). Traumatic brain injury induces an up-regulation of Hs1-associated protein X-1 (Hax-1) in rat brain cortex. Neurochem. Res. 36, 375-382. doi: 10.1007/s11064-010-0332-y

Staal, S. P. (1987). Molecular cloning of the akt oncogene and its human homologues AKT1 and AKT2: amplification of AKT1 in a primary human gastric adenocarcinoma. Proc. Natl. Acad. Sci. U.S.A. 84, 5034-5037. doi: $10.1073 /$ pnas.84.14.5034

Stanimirovic, D. B., Wong, J., Shapiro, A., and Durkin, J. P. (1997). Increase in surface expression of ICAM-1, VCAM-1 and E-selectin in human cerebromicrovascular endothelial cells subjected to ischemia-like insults. Acta Neurochir. Suppl. 70, 12-16. doi: 10.1007/978-3-7091-6837-0_4

Storch, A., Kaftan, A., Burkhardt, K., and Schwarz, J. (2000). 6-Hydroxydopamine toxicity towards human SH-SY5Y dopaminergic neuroblastoma cells: independent of mitochondrial energy metabolism. J. Neural Transm. 107, 281-293. doi: 10.1007/s007020050023

Thao, N. P., Luyen, B. T., Ngan, N. T., Song, S. B., Cuong, N. X., Nam, N. H., et al. (2014). New anti-inflammatory cembranoid diterpenoids from the Vietnamese soft coral Lobophytum crassum. Bioorg. Med. Chem. Lett. 24 228-232. doi: 10.1016/j.bmcl.2013.11.033

Togo, T., Iseki, E., Marui, W., Akiyama, H., Ueda, K., and Kosaka, K. (2001). Glial involvement in the degeneration process of Lewy body-bearing neurons and the degradation process of Lewy bodies in brains of dementia with Lewy bodies. J. Neurol. Sci. 184, 71-75. doi: 10.1016/S0022-510X(00)00498-6

Tomita, N., Morishita, R., Tomita, S., Yamamoto, K., Aoki, M., Matsushita, H., et al. (1998). Transcription factor decoy for nuclear factor-kappaB inhibits tumor necrosis factor-alpha-induced expression of interleukin-6 and intracellular adhesion molecule-1 in endothelial cells. J. Hypertens. 16, 993-1000. doi: 10.1097/00004872-199816070-00013

Tornieri, K., Welshhans, K., Geddis, M. S., and Rehder, V. (2006). Control of neurite outgrowth and growth cone motility by phosphatidylinositol-3-kinase. Cell Motil. Cytoskeleton. 63, 173-192. doi: 10.1002/cm.20115

Trebinska, A., Rembiszewska, A., Ciosek, K., Ptaszynski, K., Rowinski, S., Kupryjanczyk, J., et al. (2010). HAX-1 overexpression, splicing and cellular localization in tumors. BMC Cancer. 10:76. doi: 10.1186/1471-2407-10-76 
Tremblay, R. G., Sikorska, M., Sandhu, J. K., Lanthier, P., Ribecco-Lutkiewicz, M., and Bani-Yaghoub, M. (2010). Differentiation of mouse Neuro 2A cells into dopamine neurons. J. Neurosci. Methods 186, 60-67. doi: 10.1016/j.jneumeth.2009.11.004

Tucker, B. A., Rahimtula, M., and Mearow, K. M. (2006). Laminin and growth factor receptor activation stimulates differential growth responses in subpopulations of adult DRG neurons. Eur. J. Neurosci. 24, 676-690. doi: 10.1111/j.1460-9568.2006.04963.x

Tucker, B. A., Rahimtula, M., and Mearow, K. M. (2008). Src and FAK are key early signalling intermediates required for neurite growth in NGF-responsive adult DRG neurons. Cell. Signal. 20, 241-257. doi: 10.1016/j.cellsig.2007.10.014

Velez-Carrasco, W., Green, C. E., Catz, P., Furimsky, A., O’Loughlin, K., Eterovic, V. A., et al. (2015). Pharmacokinetics and Metabolism of 4R-Cembranoid. PLoS ONE 10:e121540. doi: 10.1371/journal.pone. 0121540

Vijayakumar, D., and Jankovic, J. (2016). Drug-induced dyskinesia, part 1: treatment of levodopa-induced dyskinesia. Drugs 76, 759-777. doi: 10.1007/s40265-016-0566-3

West, M. J. (1993). New stereological methods for counting neurons. Neurobiol. Aging 14, 275-285. doi: 10.1016/0197-4580(93)90112-O

Wong, M. L., Rettori, V., al-Shekhlee, A., Bongiorno, P. B., Canteros, G., McCann, S. M., et al. (1996). Inducible nitric oxide synthase gene expression in the brain during systemic inflammation. Nat. Med. 2, 581-584. doi: 10.1038/ nm0596-581

Wu, Y., Shang, Y., Sun, S., Liang, H., and Liu, R. (2007). Erythropoietin prevents PC12 cells from 1-methyl-4-phenylpyridinium ion-induced apoptosis via the Akt/GSK-3 $3 /$ caspase-3 mediated signaling pathway. Apoptosis 12, 1365-1375. doi: 10.1007/s10495-007-0065-9
Yang, G. Y., Gong, C., Qin, Z., Liu, X. H., and Lorris Betz, A. (1999). Tumor necrosis factor alpha expression produces increased blood-brain barrier permeability following temporary focal cerebral ischemia in mice. Brain Res. Mol. Brain Res. 69, 135-143. doi: 10.1016/S0169-328X(99)00007-8

Yasuda, T., Hayakawa, H., Nihira, T., Ren, Y. R., Nakata, Y., Nagai, M., et al. (2011). Parkin-mediated protection of dopaminergic neurons in a chronic MPTPminipump mouse model of Parkinson disease. J. Neuropathol. Exp. Neurol. 70, 686-697. doi: 10.1097/NEN.0b013e3182269ecd

Zheng, J., Shen, W. H., Lu, T. J., Zhou, Y., Chen, Q., Wang, Z., et al. (2008). Clathrin-dependent endocytosis is required for TrkB-dependent Akt-mediated neuronal protection and dendritic growth. J. Biol. Chem. 283, 13280-13288. doi: 10.1074/jbc.M709930200

Zhong, J., Deng, J., Phan, J., Dlouhy, S., Wu, H., Yao, W., et al. (2005). Insulin-like growth factor-I protects granule neurons from apoptosis and improves ataxia in weaver mice. J. Neurosci. Res. 80, 481-490. doi: 10.1002/jnr.20490

Conflict of Interest Statement: The authors declare that the research was conducted in the absence of any commercial or financial relationships that could be construed as a potential conflict of interest.

Copyright (c) 2017 Hu, Ferchmin, Hemmerle, Seroogy, Eterovic and Hao. This is an open-access article distributed under the terms of the Creative Commons Attribution License (CC BY). The use, distribution or reproduction in other forums is permitted, provided the original author(s) or licensor are credited and that the original publication in this journal is cited, in accordance with accepted academic practice. No use, distribution or reproduction is permitted which does not comply with these terms. 